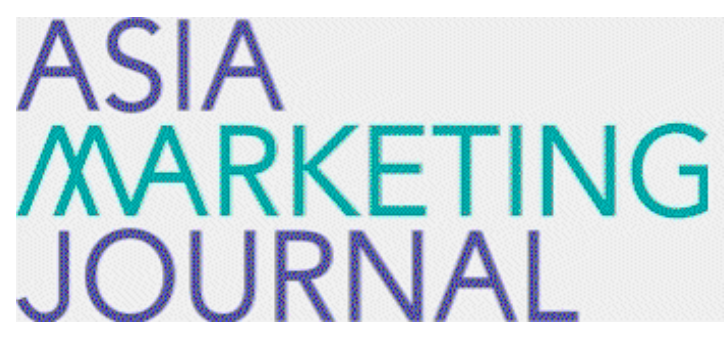

ASIA MARKETING JOURNAL

Volume 15 | Issue 2

Article 1

7-30-2013

\title{
Success Factors of Paris Baguette`s Bakery Franchise Business
}

Jae Seok Jeong

Han Nara Jeong

Ki Hyeon Ko

Moon

Hyoung Goo Kang

Follow this and additional works at: https://amj.kma.re.kr/journal

Part of the Marketing Commons

\section{Recommended Citation}

Jeong, Jae Seok; Jeong, Han Nara; Ko, Ki Hyeon; Moon; and Kang, Hyoung Goo (2013) "Success Factors of Paris Baguette`s Bakery Franchise Business," Asia Marketing Journal: Vol. 15 : Iss. 2 , Article 1.

Available at: https://doi.org/10.53728/2765-6500.1516

This Article is brought to you for free and open access by Asia Marketing Journal. It has been accepted for inclusion in Asia Marketing Journal by an authorized editor of Asia Marketing Journal. 


\title{
Success Factors of Paris Baguette's Bakery Franchise Business: Industry Competition and Core Competence Analysis
}

\author{
Jaeseok Jeong* \\ Hannara Jeong** \\ Kihyeon $\mathrm{Ko}^{* * * *}$ \\ Junghoon Moon* \\ Hyoung Goo Kang*****
}

The main goal of this study is to examine the competition intensity in the Korean bakery franchise industry and to identify the core competencies of the industry's leading company, Paris Baguette. The frameworks of PEST analysis. Cross Impact analysis, a Five Forces Model, a Value Chain, and VRIO analysis. PEST and Cross Impact analysis were employed to investigate the industry's external environment, and the results indicated that increased attention on corporate's Creating Shared Value (CSV) activities is the most influential factor among others. The analysis using the Five Forces Model found industry rivalry and substitutes were the greatest threats. Finally, the results of Value Chain and VRIO analysis identified four core competencies of Paris Baguette: its CEO's craftsmanship, e-procurement system, quality of dormant dough, and hub system. Multiple managerial implications are suggested for practitioners in the marketing area, especially in the saturated market environment.

Key words: Paris Baguette, Core Competence, Bakery Franchise

\section{Introduction}

The purpose of this research is to identify the core competence of an organization from the "resource-based view (RBV)" and its response strategies for dealing with competition by considering Paris Baguette, the leading company in the mature domestic bakery franchise market.

\footnotetext{
* Associate Professor. Graduate School of Pan-Pacific International Studies, Kyung Hee University(profjeong@khu.ac.kr)

** Researcher. Program in Regional Information, Seoul National University(eternity0145@hanmail.net)

*** Researcher, Program in Regional Information. Seoul National University(kkhfly@snu,ac.kr)

**** Associate Professor, Program in Regional Information. Seoul National University(moonj@snu.ac.kr)

***** Assistant Professor. Department of Finance, Hanyang University(hyoungkang@ hanyang.ac.kr). corresponding author
} 
The domestic "restaurant franchise" industry is among the industries deemed to have reached maturity. According to the "2011 Franchise Industry Survey" by the Ministry of Knowledge Economy and the Korea Chamber of Commerce and Industry, the restaurant franchise industry accounted for $71 \%$ (1776 enterprises) of the total franchise industry. Within the industry, the franchise bakery market, which occupies $45.7 \%$ (KRW 1.8 trillion) of the domestic bakery market (KRW 3.77 trillion), is engaged in fierce competition, led by the market leader "Paris Baguette" (HNCOM, 2011).

Since a mature industry is defined as having a plateau market divided among a handful of leading companies with little changes in market share (Ahn, 1996), a company's core competency and strategy are even more important. Companies competing in a mature industry require a thorough understanding of their core competency in order to prepare for and overcome such an uncertain environment, using well-developed strategies.

What then are strategy and core competency? Every company continuously analyzes its market conditions and sets appropriate production and marketing goals, then plans activities aligned with those goals (Han et al., 2011). "Strategy" is the planning, deciding, and executing of activities according to set goals. A sound strategy enables a company to maintain its competitive edge. In order to develop such strategies, a thorough analysis of the organization's capa- bility and its assets must first be carried out. Assets can be defined as accumulated resources from operating in a certain business, and include tangible resources such as facilities. human resources, and capital, as well as intangible resources such as technology, business rights, and brand (Srivastava et al., 1998). Capability pertains to the unique knowledge. technology, or know-how of a company accumulated over a long period. These act as a sort of adhesive, connecting necessary resources together (Han et al., 2011). If an organization can create a competitive advantage by integrating various accumulated assets, this advantage becomes the organization's "core competency" (Prahalad \& Hamel, 1990).

This analyzes Paris Baguette's core competence through various frameworks and deduces strategies suitable for a mature industry on the basis of the analysis. The specific stages of this research are shown in Figure 1. The preliminary task of deducing the core competencies and strategies of an organization requires an analysis of the external environmental factors and the industry the company belongs to (Park, 2010) : by analyzing the core competency of the organization on this basis, the foundation for creating future strategies is laid. To this end, a total of five analytical frameworks are applied in this research (Figure 1). To provide a more detailed internal and external analysis, depth interviews with corporate executives (12 hours 30 minutes) were conducted five times: these 


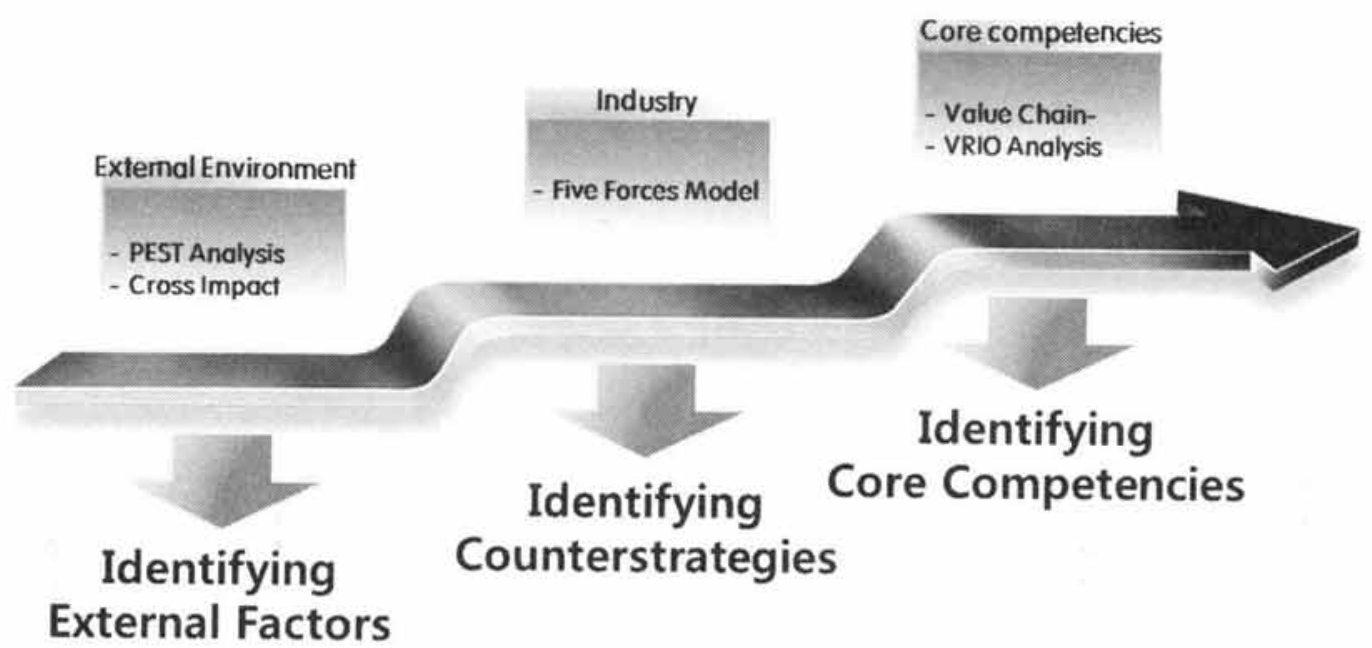

interviews were complemented by continuous interviews with the field staff to ensure the reliability of the details. Depth interviews, oneon-one interviews between a researcher and a respondent, provide valuable insight into a particular phenomenon so that researchers get information for understanding the phenomenon (Zikmund et al., 2013). The result acquired through the analysis of each framework was verified through frequent consultations with experts including professionals in the same/related fields and professors.

Using five different frameworks addressed in Figure 1, this study finally identified four core competencies of Paris Baguette: president Hur's mastership, dormant dough quality, integrated purchased systems, and efficient hub systems. From the perspective of resource-based view. this study investigated diverse types of resource of Paris Baguette, and identified its core and valuable four resources as core competence factors. From these analyses, practitioners can get valuable insights into how to compete in a mature industry and to satisfy consumer's needs. Detail analysis processes will be introduced later as shown in Figure 1.

This case study is categorized as a 'research case' based on Cutler (2004)'s classification of case study (i.e. teaching case, case history, case work, and research case). Thus, business activities based on the current social context of the bakery franchise industry in Korea will be carefully investigated and addressed.

\section{History and Present State}

\subsection{The History of Paris Baguette}

The company began in 1945 as Sang-mi-dang, one of the Paris Croissant Ltd. brands, and was 
located in Woongjin, Hwang-hae Province, home of the founder and honorary president, Chang Sung Hur. After moving Sang-mi-dang to Seoul in 1948, president Hur renamed the company Sam Lip General Food Company in 1968 and took steps to establish it as a general food company. In 1977, Shany Inc. was established as a sister company, its name being derived from the product brand Shany Cake: Shany Cake and Sam Lip became the most prominent companies in the mass production bread industry and consolidated their foothold as major companies (SPC, 2006).

When Shany entered the bakery business in 1984. it decided it needed a gentrified bakery brand, so that it established Paris Croissant in 1986 along with a separate corporate body of Paris Croissant Inc. in order to strengthen its business. Apart from the stores directly managed by Paris Croissant. Paris Baguette, a luxury French bakery brand, was presented to consumers with its first store at Gwanghwamun. Paris Baguette expanded quickly, and in 1992 surpassed 100 stores with the opening of a store at Chuncheon Central (SPC, 2006).

Powered by the growth of Paris Baguette, Paris Croissant leaped to $1^{\text {st }}$ place in 1997. In 1999, a second factory was established at Sungnam, which introduced the Coolpack System to the industry and began the "bake-off system in 1988," whereby factory-made dough was distributed to the stores and the stores baked the breads themselves. Paris Baguette, which maintained $1^{\text {st }}$ place in the domestic bakery franchise industry, began expanding overseas with the opening of the first overseas store in Shanghai in 2004 (SPC, 2006). Paris Baguette continued to grow during its 25-year history and currently operates 3,200 stores in Korea alone (SPC, 2006).

$\langle$ Table 1〉 Domestic Bakery Franchise Current Status

\begin{tabular}{c|c|c|c|c|c|c|c|c|c}
\hline & \multicolumn{3}{|c|}{2009} & \multicolumn{3}{c|}{2010} & \multicolumn{3}{c}{2011} \\
\hline & $\begin{array}{c}\text { Sales } \\
\text { (Hundre } \\
\text { d Million } \\
\text { KRW) }\end{array}$ & $\mathrm{y}-\mathrm{o}-\mathrm{y}$ & $\mathrm{M} / \mathrm{S}$ & $\begin{array}{c}\text { Sales } \\
\text { (Hundre } \\
\text { d Million } \\
\text { KRW) }\end{array}$ & $\mathrm{y}$-0-y & $\mathrm{M} / \mathrm{S}$ & $\begin{array}{c}\text { Sales } \\
\text { (Hundre } \\
\text { d Million } \\
\text { KRW) }\end{array}$ & $\mathrm{y}$-0-y & $\mathrm{M} / \mathrm{S}$ \\
\hline $\begin{array}{c}\text { Paris } \\
\text { Baguette's }\end{array}$ & 10,015 & $27.9 \%$ & $69.0 \%$ & 13.126 & $31.1 \%$ & $61.1 \%$ & 15.733 & $19.9 \%$ & $64.4 \%$ \\
\hline $\begin{array}{c}\text { Tous Les } \\
\text { Jours }\end{array}$ & 6.489 & $10.4 \%$ & $23 \%$ & 7.381 & $13.7 \%$ & $34.4 \%$ & 7.902 & $7.1 \%$ & $32.3 \%$ \\
\hline $\begin{array}{c}\text { Crown } \\
\text { Bakery }\end{array}$ & 717 & $-16.5 \%$ & $5 \%$ & 584 & $-18.5 \%$ & $2.7 \%$ & 427 & $-26.9 \%$ & $1.7 \%$ \\
\hline $\begin{array}{c}\text { Shilla } \\
\text { Bakery }\end{array}$ & 394 & $48.4 \%$ & $3 \%$ & 381 & $-3.3 \%$ & $1.8 \%$ & 385 & $1.0 \%$ & $1.6 \%$ \\
\hline
\end{tabular}




\subsection{The Present State of Paris Baguette}

The current domestic bakery market is worth KRW 4.6 trillion (2011), of which the big four (Paris Baguette, Tous Les Jours, Crown Bakery, and Shilla Bakery) reached KRW 2.4 trillion in sales with a market share of $52.0 \%$ of the entire bakery market. The market share of bakery franchise companies is continually increasing (HNCOM, 2012). In particular, Paris Baguette displayed a high growth rate and market share, in the context of 2011 market conditions, with $64.4 \%$ of the big four being those of Paris Baguette.

\section{External Environment Analysis}

\subsection{PEST Analysis}

The tool used for analyzing a company's external environmental factors is called "PEST Analysis." PEST pertains to the macro-environmental factors that a company cannot control, and is an acronym for Political, Economic, Social, and Technological fields (Downey, 2007). The PEST analysis performed in this research underwent a validation process by related workers and professors. The results are shown in Table 2.

The results identify four changes in the political environment as politico-environmental factors that influenced the bakery franchise

〈Table 2〉 The Results of PEST Analysis

\begin{tabular}{|c|c|}
\hline $\begin{array}{c}\text { Political } \\
\text { Environment }\end{array}$ & $\begin{array}{l}\text { - Restriction of expanding business due to Fair Affiliate Business Transactions Law } \\
\text { - Restriction of expanding business due to regulations on specified business areas for } \\
\text { SSM, and gross volume institution } \\
\text { - New politics and regulatory changes due to Presidential election } \\
\text { - Acceleration of market opening due to FTA }\end{array}$ \\
\hline $\begin{array}{c}\text { Economic } \\
\text { Environment }\end{array}$ & $\begin{array}{l}\text { - Increase in production cost due to rising international oil and crop prices } \\
\text { - Shrinkage of household spending due to long-term economic recession } \\
\text { - Uncertain US and Chinese economic conditions } \\
\text { - Decline in exports }\end{array}$ \\
\hline $\begin{array}{l}\text { Social/Cultural } \\
\text { Environment }\end{array}$ & $\begin{array}{l}\text { - Increased attention on corporations' social responsibility and creating shared value } \\
\text { - Fair business and redistribution practices from 'Economic Democratization' } \\
\text { - Entrance of silver generation of baby boomers who comprise } \frac{1}{4} \text { of total population } \\
\text { - Greater demand for instant food due to women's advancement in society } \\
\text { - More attention on health and organic products (Well-being) }\end{array}$ \\
\hline $\begin{array}{l}\text { Technological } \\
\text { Environment }\end{array}$ & $\begin{array}{l}\text { - Spread of SNS culture } \\
\text { - Increasing need for sustainable innovation in order to meet diversified consumer needs } \\
\text { - Greater importance for 'big data' } \\
\text { - Acceleration of softer fusion for efficient manufacturing cost }\end{array}$ \\
\hline
\end{tabular}


industry: "Regulations Governing Business Expansions under the Franchise Business Trade Fairness Act" and "Regulations Governing Business Expansions under the SME-Suitable Industries and Total Quantity Policy" implemented by the Fair Trade Commission, changes in the political structure and system due to the presidential election, and the accelerated opening of the country's market due to the signing of the FTA. Economic environmental factors that influenced the bakery franchise industry included the increase of manufacturing costs because of the rise of oil and grain prices, the shrinking of household consumption due to the long recession, uncertainty in the American and Chinese markets because of the global economic slump, and a decreasing trend of exports.

Further, socio-cultural environmental factors influencing the market were identified. These included the increased interest in corporate social responsibility (CSR), in Creating Shared Value (CSV), in fair trade and distribution as a result of economic democratization, the aging of the baby boomer generation into the silver generation that accounts for one-fourth of the population, the increased demand for convenience foods following the entrance of women into public life, and the increased interest in healthy and organic foods due to the fitness trend.

Finally, technological environmental factors included the spread of SNS technology, the necessity for continuous technological innovation following the diversification of consumer $\mathrm{de}^{-}$ mands, the rising importance of Big Data, and the acceleration of software fusion to promote cost-efficient manufacturing.

\subsection{Cross-Impact Analysis}

Cross-impact analysis is an analytic tool to evaluate the relationship between factors and the influence each factor has on the major environmental factors deduced from the PEST analysis. Using the major factors identified from the cross-impact analysis, a cross-impact matrix was created (Proctor, 2000).

This study first deduced the major environmental factors that may greatly affect the domestic bakery franchise industry, using PEST analysis with expert feedback to find the political factors: likewise, it deduced the economic factors, which were found to include the limiting of affiliated stores' expansion, the increase in manufacturing costs, and the decrease in household consumption; also, the socio-cultural factors, which were found to be the increased interest in shared values and the spread of fitness trends. The study then found the technological factor, which was determined to be the spread of SNS. The analysis results are displayed in Appendix 1.

Each of the six major factors identified above was given an evaluation score ranging from -2 (negative impact) to 2 (positive impact). As a result of conducting the cross-impact analysis, 
the "increased interest in the creation of corporate shared values" category was identified as having the greatest impact, with a total score of 5 points, making it the core external environmental factor influencing the bakery franchise industry (Appendix 2). In other words, consumer interest in a win-win corporate culture and CSV greatly influenced the limits on franchise expansion and increased manufacturing price. This can be interpreted as follows: as consumers increasingly value the coexistence between companies and between companies and laborers, senseless business expansion becomes harder, and manufacturing costs rise with raw material and labor costs (Jones et al., 2011).

Furthermore, the shrinking of household consumption and the spread of SNS were found to influence the bakery franchise industry. When household consumption shrinks, the company cannot forcedly expand affiliated stores, and interest in labor wages, which determine household consumption, increases: whereas the analysis suggests that consumption positively affects franchise expansion limits and rising interest in shared values, household consumption also appears to negatively affect the spread of the fitness trend (Jung, 2007). Moreover, as SNS spreads and consumers more actively share information and knowledge among themselves, the desire for corporate coexistence increases, which may heighten the need for corporate social responsibility, while positively influencing the spread of the fitness trend (Seo et al., 2011).
On the other hand, the rise of manufacturing costs and the limits on franchise expansion were highly dependent on other environmental factors. The increase of manufacturing costs was due to franchise regulations, increased civic interest in shared values, and the spread of the fitness trend: the limit on franchise expansion was also affected by the decrease in household consumption, rising interest in shared values, and the spread of SNS (Kim et al. 2012). The influence of each factor and the correlation of the analysis results have been detailed in the quadrant in Appendix 2.

\section{Domestic Bakery Franchise Industrial Analysis}

\subsection{The Five Forces Model of the Domestic Bakery Franchise Industry}

The "Five Forces Model" suggests that the competitiveness or the final potential profit of a certain industry is decided by five basic forces (Song at al., 2002). These five forces are (1) intensity of industry competition, (2) threat of new entrants, (3) buyer bargaining power, (4) supplier bargaining power, and (5) the threat of substitutes. By analyzing the factors that compose each force, a strategy to identify the profitability and the main sources of competi- 
tion can be established (Porter, 2008).

Figure 2 displays the Five Forces Model of the domestic bakery franchise industry, as seen by related experts and professors. A thorough analysis deduced from Figure 2 can be found in Appendix 3, with each item evaluated on a 5-point scale with 0.1-point intervals. The higher the score is, the higher the threat, and the greater is the intensity of competition.

A look at the figure above shows that industry competition intensity scored 3.8 points and the threat of substitutes 4.3 points, making these two forces the greatest threats in market competition. On the other hand, the threat of new entrants turned out to be relatively low. This may be explained by the bakery market's overall maturity, which made entry difficult for new companies (Park and Park, 2012).

A major source of high intra-industry competition is the expansion of major companies into the franchise bakery industry. Conglomerates such as CJ expanded into the bakery franchise as part of their business diversification and with strong support from its parent company CJ has been rapidly growing and achieving market share similar to Paris Baguette. The detailed analysis has been articulated in Appendix 3.

Meanwhile, the bargaining power of suppliers also scored relatively high due to the suppliers of the main ingredients for baking-flour, sugar, and milk-holding an oligopoly position. Additionally. the bargaining power of buyers, according to the standard Five Forces Model, was distributed among affiliated stores and consumers for the purposes of analysis, taking account of the particular nature of this franchise industry. Both scored around 3 points, displaying an average impact. The threat of substitutes, which scored over 4 points, appeared to be the most influential. However, bread is more of a snack than a staple considering the present Korean food culture (Ryu et al., 2011), and there are many food companies that can offer substitutes for bread as a snack. Cafes, snack bars, noodle stores, and pastry companies can all be considered competitors of the franchise bakery companies: moreover, the mass production bread market and the window bakery market are also reciprocal substitutes, and therefore, competitors.

\subsection{Paris Baguette's Response Strategy deduced from the Five Forces Model}

Analysis of the bakery franchise industry using the Five Forces Model showed that among the five forces, competition intensity within the industry and the existence of substitutes were the more serious threats to the industry. Table 3 shows the response strategies selected by Paris Baguette(PB) in such circumstances.

\subsubsection{Response strategy to substitute threats}

First, $\mathrm{PB}$ is transforming its simple bakery 
〈Figure 2〉 Domestic Bakery Franchise Industry analysed by Five Forces Model
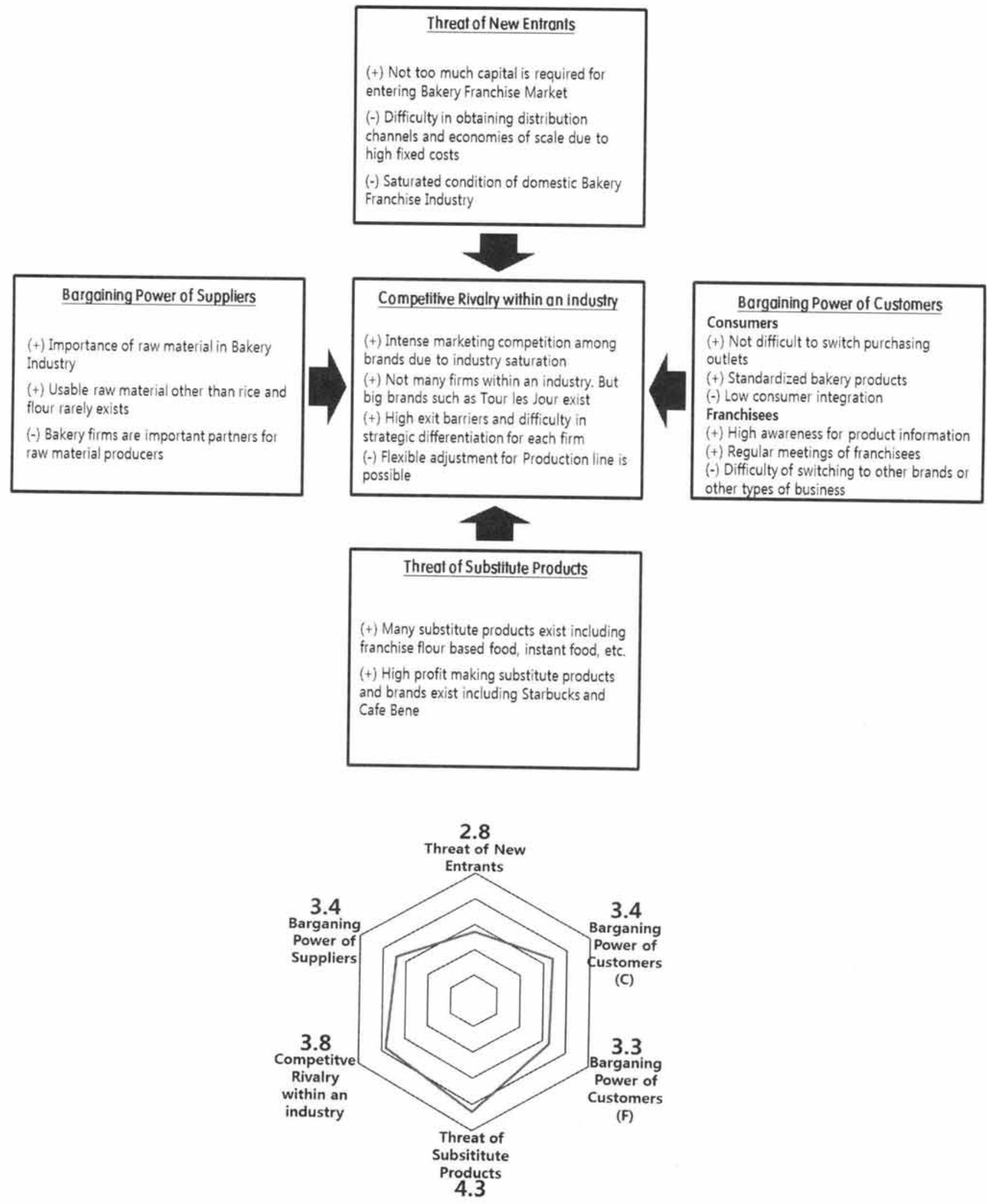

Success Factors of Paris Baguette's Bakery Franchise Business: Industry Competition and Core Competence Analysis 9 
〈Table 3〉 Paris Baguette's Counterstrategies

\begin{tabular}{c|l}
\hline Factors of Threat & \multicolumn{1}{c}{ Paris Baguette's counterstrategies } \\
\hline $\begin{array}{c}\text { Threat of Substitute } \\
\text { Products }\end{array}$ & $\begin{array}{l}\text { - Redesigning stores as cafes to compete with substitute products(Coffee shops, } \\
\text { café franchises) }\end{array}$ \\
\hline $\begin{array}{c}\text { Business diversification by SPC through corporate advancement into substitute } \\
\text { industries using its brands such as Bizeun and Pascucci }\end{array}$ \\
$\begin{array}{c}\text { Intense competitive } \\
\text { rivalry within an } \\
\text { industry }\end{array}$ & $\begin{array}{l}\text { - Global business expansion through exporting } \\
\text { - Providing differentiated service from rival firms by redesigning stores as cafes }\end{array}$ \\
\hline
\end{tabular}

stores into café-style stores. In a mature market, categorical boundaries need to be removed. When an accustomed category no longer adheres to a fixed concept, the values may change within the existing framework (Kim, 2012). Moreover, in response to the rapidly growing substitutes presented by coffee specialty stores and "café franchises" since 2000. PB's transformation into café-style stores has allowed it to offer customers new values that were not available in the existing framework, and has given it a dominant position over competing substitutes.

Moreover, increased investment at the SPC group level into not only Paris Baguette, but also Pascucci (café), and Bizeun (rice cake franchise), signifies active expansion into substitute industries. Pascucci's business expansion is an active response strategy, not only to the threats of the café franchises as a substitute market, but also as a reverse expansion of Paris Baguette's luxury product line into the substitute market.

\subsubsection{Response strategy to intense competition}

As the analysis has so far shown, the domestic bakery franchise industry has reached saturation, i.e., it has reached maturity. The era of globalization provides us with opportunities (Kim et al., 2013). A strategy Paris Baguette can use in the current situation is global expansion. In a mature market, consumers are highly informed about the product, and. therefore, product preference is quite clearly differenciated (D’Souza \& Rao, 1995). This explains the need to depart from the standardized domestic market and actively develop overseas markets in order to generate new growth and demand. Currently. Paris Baguette is enlarging its overseas operations. Concentration is focused on Southeast Asia more than on any other continent: the logic behind this is that the market is not large compared to that of the U.S. and Europe, though demand for the product remains strong, influenced by the Korean 
〈Table 4〉 the state of Paris Baguette's overseas stores

\begin{tabular}{c|c|c|c|c}
\hline Country & China & USA & Vietnam & Singapore \\
\hline Stores & 105 & 24 & 6 & 1 \\
\hline
\end{tabular}

wave (Park, 2012).

Another strategy employed by Paris Baguette against the very intense competition within the industry is backward integration. When a company adopts backward integration, it can reduce distribution costs and create synergies from shared resources (Im et al., 2011), allowing it a cost advantage as it can sell at lower prices than its competitors. By acquiring, in 2008, "Mildawon," a professional flour processing company. Paris Baguette overcame the problems of flour's price instability as well as of flour supply and demand, which was significant since flour is the most important ingredient (Ryu, 2012). This acquisition has also greatly helped in improving product quality, since the company can now mill flour according to its products' characteristics.

Finally. CSV can be achieved through direct contracts with producers. The core principle of CSV goes beyond the simple demand of corporate social responsibility and ties business success to social development (Porter \& Kramer. 2011): moreover, in the 21st century, "social enterprises" are receiving great attention all over the world (Kim, 2012). Paris Baguette's direct contracts with regional farms can be linked to CSV, and both parties reap benefits, as follows.
First, agricultural products used in baking can be supplied more consistently, and with it a continuous and stable income can be assured for farmers. Second, specialized raw material for bakery products can be acquired. For instance, strawberries used for cakes require a different quality from that sold in the market. Therefore, a direct contract with the farm enables the company to request the production of fruits that can be used in the final product, which not only ensures stable income for the farms, but also contributes to enhancing the product quality and homogeneity of Paris Baguette. Moreover, cooperation with the production farms at a regional cluster level allows for joint $\mathrm{R} \& \mathrm{D}$. Currently, Paris Baguette is moving ahead with the formation of a joint corporate body with farmers in the Pyongchang region for dairy product manufacture and fresh agricultural production in order to vitalize the local economy and realize the value of coexistence, while seeking to acquire a steady, customized raw material supply at the same time. Although Paris Baguette has already achieved remarkable success in the domestic bakery franchise market, in order to create a more differentiated corporate image it must pursue shared value growth (Borgonovi et al., 2011), which embraces both the economy and society. 


\section{Analysis on the Core Competency of Paris Baguette}

The analysis of the external environment of Paris Baguette and the industry has been performed above. As mentioned in the introduction, assessment of internal capabilities, along with external environmental and industry analysis, lays the foundation for strategy development. For the analysis of internal capabilities, value chain and VRIO analysis are performed.

\subsection{Value Chain Analysis}

A value chain is the process by which a com- pany creates added value through a series of corporate activities, and is divided into primary activities and support activities. Support activities consist of planning, research and development, human resource, financial activities, and accounting, while primary activities are manufacture, distribution, marketing, sales, and services (Porter, 1998).

Paris Baguette's value chain based on the data from five interviews and research using internal data and secondary material is shown in Figure 3.

\subsubsection{Support Activities}

Support activities of the value chain are ac-

〈Figure 3〉 Value Chain of Paris Baguette

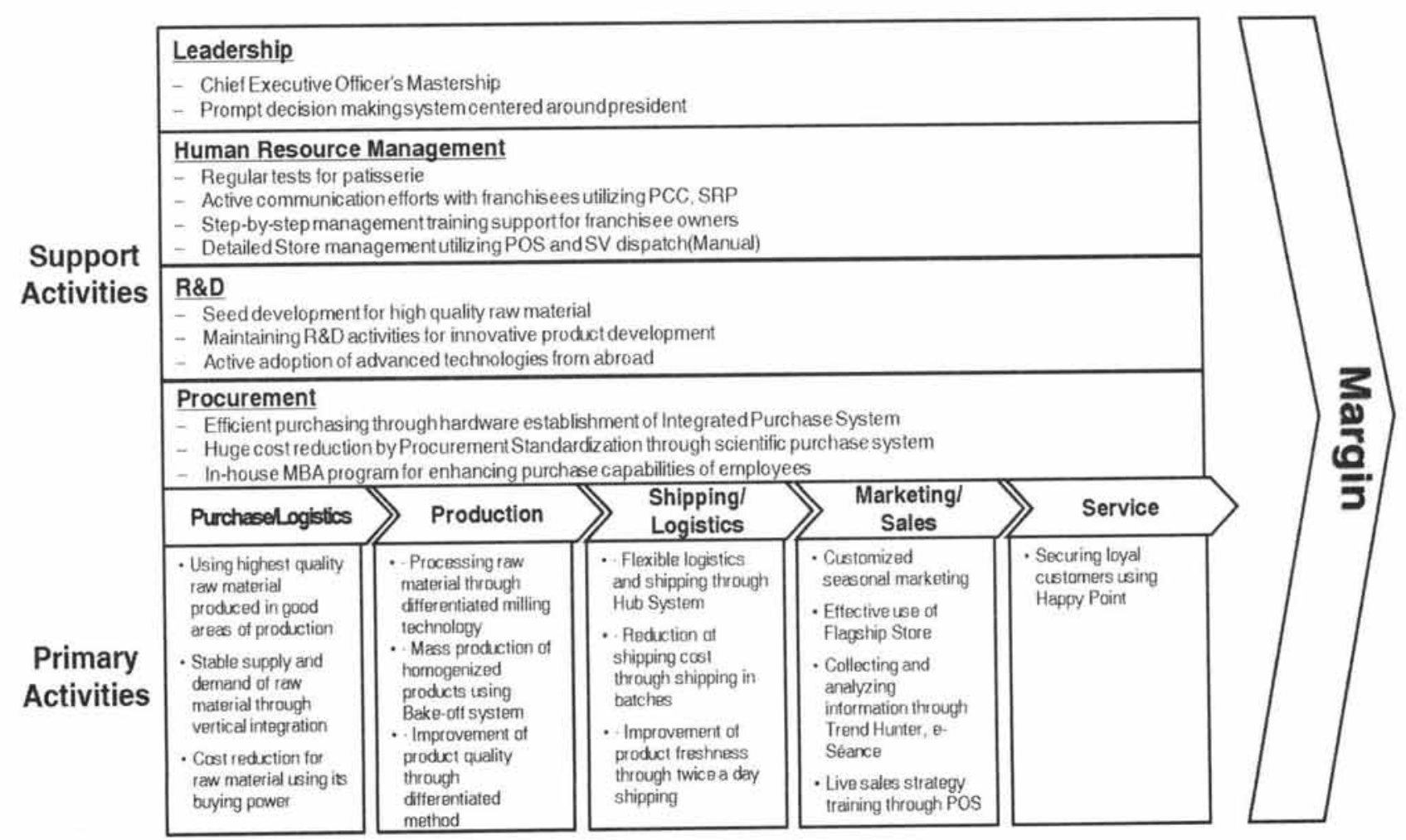


tivities that support and assist the company's primary and core activities (Lee. Kim, 2011). In this research, support activities were divided into (1) leadership, (2) human resource management, (3) technology development, and (4) procurement in line with the characteristics of the bakery franchise industry.

First, leadership requires a quick decisionmaking system centered on the CEO. Unlike listed companies, unlisted companies like the SPC group do not have to worry about the stockholders. This enables the CEO to exercise his management leadership and allows for quick decision making (Minichilli et al., 2010). Paris Baguette made the most of this advantage and reflected the CEO's intentions in various aspects of management. As a result, Paris Baguette grew into the number one bakery franchise. Paris Baguette's quality and business philosophy centering on coexistence stems from its president, Hur, the owner of the SPC group. Even with a zero margin. PB continually manufactured and sold high-quality bread, implementing quality-centered management. Moreover, to promote coexistence with minor bakery companies and mom-and-pop bakeries, PB decreased alliance discounts from telecommunication companies (Moon, 2006) and has donated bread to FoodBank since 1998, reflecting the CEO's philosophy of quality and coexistence underpinning corporate policies.

Core capabilities can also be found in Paris Baguette's human resource management. Paris
Baguette manages the service quality of affiliated stores by supporting franchise employees and strives for consumer satisfaction. Periodic examinations on Craftsman Bread Making have been administered, supervisors are dispatched to support store owners and act as management consultants to them, and there is even a support program for those who wish to apply for an MBA course (Kang, 2012).

Meanwhile, Paris Baguette's R\&D section continually strives for technological innovations, including developing bakery patents like its "Tangjong" technique and importing foreign bakery technology.

In terms of procurement, $\mathrm{PB}$ purchases raw materials specially tailored to suit its products through a special ordering system, and was the first in the world to establish the hardware for an integrated purchase system. By standardizing procurements through a scientific purchase system, PB has reduced costs, enabling it to sell products at a lower price compared to other franchise bakeries. To support such systematic and strategic procurement company-wide, an in-house MBA program was established to keep improving the purchase capabilities of employees.

\subsubsection{Primary Activities}

According to Michael Porter (1990), primary activities can be divided into the following five areas: inbound logistics, operations, outbound 
logistics, marketing \& sales, and services.

In the case of Paris Baguette, the strong points of their inbound logistics can largely be divided into three categories. First, Paris Baguette uses top-quality raw material grown only by good sources. Paris Baguette conducted internal studies on the optimal mix of materials for various types of bread, and consequently obtained the required material of high quality from various sources. Meanwhile, by acquiring the professional mill company Mildawon in 2008, it vertically systemized the material supply system: in essence, a backward integration (Ryu et al., 2012). Thus, Paris Baguette obtained a stable source of materials as well as bargaining power in dealing with the powerful mill industry (Ryu et al.. 2012). Besides, another identified internal capability is the reduction of raw material costs due to the rapid growth in the quantity it purchases (Paris Croissant. 2012).

Its manufacturing strong points are a raw material processing method using a differentiated milling technology, the mass production of homogeneous products using the bake-off system, and the upward leveling resulting from such differentiated methods. After the acquisition of Mildawon in 2008, Paris Baguette developed the optimal flour mix and mill technology. It was also the first in Korea to adopt the bake-off system that supplies dormant dough manufactured in factories to each store, which then bake and sell directly to the customers, thereby enabling the standardization of product quality. Paris Baguette holds especially high levels of technology and work methods in processing dormant dough, which makes the manufacturing aspect its strongest advantage among the primary activities.

Next, Paris Baguette's strong points in relation to distribution are the following: elastic distribution that uses hub systems, reduction of distribution costs through en bloc delivery, and the improvement of product freshness through twice daily deliveries. The most important part of the aforementioned bake-off system was the establishment of a logistics system (Ryu et al.. 2012). Paris Baguette raised the efficiency of the delivery system, improved the freshness of products, and prevented products from going bad by means of the "Coolpack" system that adjusts temperature and storage time by the gram twice a day (Ryu et al., 2012).

Paris Baguette's strengths in relation to marketing and sales are specialized seasonal marketing, the effective use of the flagship stores located in Itaewon's Passioin5 and Gangnamdaero, trend hunting, an autonomous feedback community such as e-Séance, and real-time sales strategy coaching through the POS system. Paris Baguette especially concentrates on $\max ^{-}$ imizing sales through the effective use of timesensitive seasonal marketing rather than commercial marketing through the media. Also, while strengthening the brand image through luxurious flagship stores or café-style stores. Paris 
Baguette differentiates itself from other competing companies by promoting a distinguished corporate image (Jung, 2011).

Finally. Paris Baguette's strength in relation to customer service lies in its "Happy Point" system, which helps achieve customer loyalty. SPC Group, Paris Baguette's parent company, issued the Happy Point card, a sort of mileage savings card, in 2000, to help strengthen customer loyalty. It was the first of its kind. The Happy Point card can be used not only in SPC-affiliated stores such as Dunkin Donuts and Baskin Robbins 31, but also in various other affiliated stores. By establishing the first mileage system. Paris Baguette has succeeded in improving customer loyalty and increasing repurchase rates.

\subsection{VRIO Analysis}

VRIO analysis, suggested by Barney (1995. 2011), is a framework that can analyze the continuous competitive advantage of the management resources of a company from a resource-based view, a theory established by Rumelt (1984). VRIO is a useful analytic tool in evaluating the synthesis of the management resource, rarity, imitability, and organizational characteristics of a company. After Barney (1995), Collis and Montgomery (1995) suggested additional analysis using VRIO in terms of durability, appropriability, and superiority, thereby expanding the VRIO: for the purpose of this research, however, the VRIO suggested by Barney was the one used to analyze Paris Baguette's management resources.

In order to enable VRIO analysis, the management resources owned by the organization must first be identified. This research's value chain analysis found the major management resources of Paris Baguette. which are outlined in Table 5. Major management resources were deduced from the nine management activities that compose the value chain in Figure 3, and experts validated them, with scores ranging from -2 to 2 .

A total of 19 major management resources were identified from the nine management activities existing on the value chain. Resources identified as core competencies were (1) the CEO's artisan spirit, (2) the integrated purchase system, (3) the quality of the dormant dough, and (4) the hub system distribution.

First, the craftsman philosophy of SPC Group's CEO, President Young-In Hur, is the basis for all employees' sharing the quality and focused onsite philosophy. President Hur has emphasized thorough sanitation and safety in the whole process, from manufacturing products to delivery to customers, and has practiced food safety management by establishing systems for quality improvement (Jung, 2012). Such an artisan spirit was the basis for Paris Baguette winning the top place two years in a row at the KS-SQI run by the Korean Standards Association (Lee, 2012), and the driver behind Paris Baguette 
〈Table 4〉 VRI0 Analysis

\begin{tabular}{|c|c|c|c|c|c|}
\hline Resource / Capability & Valuable & Rare & $\begin{array}{l}\text { Hard to } \\
\text { Imitate }\end{array}$ & $\begin{array}{l}\text { Exploited by } \\
\text { Organization }\end{array}$ & $\begin{array}{c}\text { Core } \\
\text { Competence }\end{array}$ \\
\hline \multicolumn{6}{|l|}{ Leadership } \\
\hline o Chief Executive Officer's Mastership & 2 & 2 & 2 & 2 & $\mathrm{Y}$ \\
\hline o Speedy Decision Making System(unlisted corporation) & 1 & 1 & 0 & 0 & $\mathrm{~N}$ \\
\hline \multicolumn{6}{|l|}{ Management of Franchisees } \\
\hline o Regularly held tests for patisseries & 1 & -2 & -1 & 1 & $\mathrm{~N}$ \\
\hline o Educational support such as MBA for franchisee owners & 1 & -1 & -1 & 1 & $\mathrm{~N}$ \\
\hline - Management of franchisee owners using POS and SV & 1 & 1 & -1 & 2 & $\mathrm{~N}$ \\
\hline \multicolumn{6}{|l|}{ R\&D } \\
\hline - Adoption of advanced technologies from abroad & 1 & -1 & 0 & 1 & $\mathrm{~N}$ \\
\hline \multicolumn{6}{|l|}{ Procurement } \\
\hline o Integrated Purchase System & 2 & 2 & 2 & 2 & $\mathrm{Y}$ \\
\hline $\begin{array}{l}\text { - Enhancing purchase capabilities through in-house } \\
\text { MBA education }\end{array}$ & 2 & 0 & 0 & 1 & $\mathrm{~N}$ \\
\hline \multicolumn{6}{|l|}{ Purchase/Logistics } \\
\hline $\begin{array}{l}\text { - Uses highest quality raw materials from good areas of } \\
\text { production }\end{array}$ & 1 & -1 & 0 & 2 & $\mathrm{~N}$ \\
\hline o Backward Integration(Acquisition Mildawon) & 2 & 2 & 0 & 1 & $\mathrm{~N}$ \\
\hline \multicolumn{6}{|l|}{ Production } \\
\hline - Mass production using Bake-off system & 2 & -1 & -1 & 2 & $\mathrm{~N}$ \\
\hline oSteam method & 0 & 1 & 1 & 0 & $\mathrm{~N}$ \\
\hline o Dormant dough quality & 2 & 1 & 2 & 2 & $\mathrm{Y}$ \\
\hline \multicolumn{6}{|l|}{ Shipping Logistics } \\
\hline oShipping in batches using Hub System & 2 & 1 & 2 & 2 & $\mathrm{Y}$ \\
\hline \multicolumn{6}{|l|}{ Marketing/Sales } \\
\hline o Effective seasonal marketing & 2 & -1 & -1 & 2 & $\mathrm{~N}$ \\
\hline oFlagship stores & 2 & -1 & 1 & 1 & $\mathrm{~N}$ \\
\hline - Market analysis using in-house customer community & 1 & -2 & -1 & 2 & $\mathrm{~N}$ \\
\hline o Sales coaching through POS & 2 & -2 & -1 & 2 & $\mathrm{~N}$ \\
\hline \multicolumn{6}{|l|}{ Service } \\
\hline o Happy Point & 2 & -2 & -1 & -1 & $\mathrm{~N}$ \\
\hline
\end{tabular}

becoming the leading company in the fierce quality-driven market of bakery franchise.

The integrated purchase system for procurements was also identified as a core competency. By introducing the e-procurement system in 2008, Paris Baguette integrated a purchase system that depends on hardware. The e-procurement streamlines the organization's purchase system and enables the procurement management division to manage all purchases for the entire enterprise. From general office supplies having low unit prices to raw materials and 
expensive machines, all departmental purchases are systematically managed, ensuring the transparency of the purchase and allowing for bulk purchasing. Moreover, the database derived from utilizing the system has enabled "scientific purchases." This has helped to increase the price competitiveness of the products, giving Paris Baguette a decisive cost advantage over its competitors.

Paris Baguette's third core competency is the quality of its dormant dough. Dormant dough is made in the bakery by suppressing the fermentation of dough using a freezer and then storing it in a fridge (Lee et al., 2044). It is a critical element in the bakery franchise industry that must produce bread in large quantities. The quality of the dough is directly related to the taste of the bread: hence, the quality differentiation of the dough leads to taste differentiation. Paris Baguette, whose bakery business roots go back to "Sangmidang" in the 1940s, has a marked characteristic in the dough quality technology. Paris Baguette's dough manufacturing techniques are based on its special know-how: therefore, although competitors may benchmark the manufacturing facilities, the mix ratio of ingredients and yeast-based techniques is hard to imitate.

Finally, Paris Baguette's hub system was singled out as its main core competency. Effective use of logistics requires large supply units: planned transport/delivery: and complex, en bloc transportation (Im et al., 2011). Paris Baguette met the above three requirements through its hub system, accomplishing both efficiency in logistics (cost reduction) and high effectiveness (maintenance of quality). Paris Baguette's manufacturing plants are dispersed in various locations, including Sungnam, Daegu, and Wonju. Having manufacturing points in various locations enables elastic regional delivery, and while competitors deliver only once every three days, Paris Baguette delivers twice a day. The frequent delivery enhances the safety and freshness of easily decaying products such as sandwiches and cakes, allowing for better quality products to be supplied to the customers. Moreover, promotional materials are delivered to the stores on time, allowing for effective marketing.

\section{Conclusion and Suggestion}

The purpose of this research was to analyze the core competency of Paris Baguette, the leading company in the domestic bakery franchise industry, which is a mature industry. Paris Baguette, which began as a small bakery called "Sangmidang," is recognized as the strongest in the domestic bakery franchise industry, with a $73 \%$ share in terms of sales. In this research, five frameworks, that of PEST analysis, Cross Impact analysis, the Five Forces Model, a Value Chain, and VRIO analysis were used to analyze the core competencies of Paris 
Baguette, which has maintained its top position in the industry over a long period.

The PEST analysis and Cross Impact analysis used to analyze the external environment identified the limits on franchise expansion under the "SME-Suitable Business" system and recent increased interest in CSV as major external environmental factors. Such results could be negatively interpreted from the Paris Baguette perspective, but could also present opportunities. From Paris Baguette's standpoint, creating shared values was a great opportunity to enhance its corporate image.

According to the results of the Five Forces Model applied to industrial analysis of the domestic bakery franchise, the threats of substitutes and intra-industrial competition were identified. Paris Baguette's response strategy toward such threats can be found in 〈Table 3〉. First, in response to the threat of substitutes, Paris Baguette adopted a strategy of business diversification by transforming its stores into café-style outlets and by increasing investments in SPC-affiliated brands such as Pascucci. Further, in response to the high intra-industry competition, Paris Baguette planned and executed global expansion strategies, differentiating through café-style stores, vertical affiliation based on backward integration, and creating shared values by the expansion of direct contracts.

Finally, Value Chain and VRIO analysis were used in core competency analysis to investigate the management resources of Paris Baguette.
Out of the nine management activities that form the value chain, 19 major management resources of Paris Baguette were extracted, which were again analyzed with regard to core competency, using VRIO. As a result, the CEO's artisan spirit, the integrated purchase system, the quality of the dormant dough, and the hub system were identified as core competencies. Not only did they greatly affect PB's sales, but these factors also were found to be highly unique resources that were hard for competitors to imitate.

By analyzing the lead company in a mature market, which represents a pioneering work in Korea, this research serves as a good reference material for companies in a fiercely competitive and saturated market.

Our study provides multiple managerial implications for practitioners. First, the role of CEO mastership to compete in the saturated market is highlighted. Due to President Hur's artisan spirit, all employees could share the confidence on the product quality and his field-centered philosophy has resulted in gaining market share from competitor in the saturated market. Second, the integrated purchase systems lower the production cost dramatically, resulting in cost leadership and guaranteeing higher margin compared with its competitors. Paris Baguette's integrated purchase system is a rarely found example of best practice in the procurement. Lastly, efficient decision making process and well-designed hub systems make an organization flexible and agile in responding 
to market signals. Paris Baguette's efficient decision making process and hub systems are its valuable assets to gain customers' love by catching and applying customers' needs to its various marketing campaign programs much quicker than its competitors.

Suggestions for follow-up studies that can be done on the basis of this research are as follows. First, a more in-depth research on Paris Baguette's CSV is necessary. Paris Baguette is currently performing and planning various CSVrelated activities, and these activities would surely be an interesting research topic. Also, by investigating CSV cases, not only of Paris Baguette, but also of the whole restaurant industry, such research would become meaningful at the present juncture where "coexistence" is becoming a greater issue. Another research suggestion is the need for quantitative research on coexistence. With the current "SMESuitable Business Act" and "Total Quantity Limit" regulations, the expansion of existing franchises has been limited. A question that can be asked at this point is "Does the franchising of large companies negatively affect small stores?" If the economic effects could be deduced from quantitative data, a clear direction for CSR and the validation of the current regulations legitimacy may be provided.

〈Received March 2. 2013〉

〈Revised April 17. 2013〉

〈Accepted April 22. 2013〉

\section{References}

Ahn, G. H (1996). "Strategies of Matured Products," Monthly Marketing, 30(12), 64-67. Barney, J. B (1995). "Looking inside for competitive advantage," Academy of Management Executive, 9(4), 49-61.

Barney, J. B (2001), Gaining and Sustaining Competitive Advantage(2nd ed.), MA: Addison-Wesley.

Borgonovi, V., Meirer. S., sharda. M., and Vaidyanathan. L (2011), “Creating shaerd value in India: how Indian corporations are contributing to inclusive growth while strnegthening their competitive advantage," FSG, www.fsg.org.

Byun, S. E. and E. S. Cho (2011), “Categorizing Quality Features of Franchisees: In the case of Korean Food Service Industry," Korea Distribution Association, 16(1), 95-115.

Chong, Y. K. and E. A. Min (2011), “A Study on Concept Revitalization of Brand Bakery: Focused on PARIS BAGUETTE," The Tourism Sciences Society of Korea, 35(8). 261-281.

Collis, D. J., \& Montgomery. C (1995), "Competing on resources: Strategy in the 1990s," Harvard Business Review, July-August. 119-128.

Cutler, A (2004), "Methodical failure: the use of case study method by public relations researchers," Public Relation Review, 30 
(3), 365-375.

Downey, J (2007), Strategic Analysis Tools. London: CIMA.

D'Souza, G., \& Rao, R. C (1995), "Can Repeating an Advertisement More Frequently Than the Competition Affect Brand Preference in a Mature Market?," Journal of Marketing. 59(2), 32-42.

Grunert, K., \& Ramus, K (2005), “Consumers' willingness to buy food through the internet: A review of the literature and a model for future research," British Food Journal, 107(6), 381-403.

Han, S. H (2012), “Paris Baguette, Making Reliable Products which Make High Customer Reliability," Chosun.

Han, S. M., Y. W. Ha. And D. R. Jang (2011), "Competitive Advantage Marketing Strategy $3^{\text {th }}$ edition. Seoul: Parkyoungsa.

HNCOM (2011), “2011-2012 “The Korean Food Yearbook". Seoul: HNCOM.

HNCOM (2012), “2012-2013 “The Korean Food Yearbook". Seoul: HNCOM.

Heiniö, L., Liukkonen. H., Katina. K., Katina. K., Myllymäki. O., and Poutanen. K (2003). "Milling fractionation of rye produces different sensory profiles of both flour and bread," LWT - Food Science and Technology, 36(6), 577-583.

Henry, A (2008), Understanding Strategic Management(1st ed.). Oxford: OUP.

Jones, D. T., Huchzermeier. A., and Mitchell. A (2011), “Crating Shared Value with
Consumers," International Commerce $\mathrm{Re}^{-}$ view, $10(1), 2-3$.

Jung, E. J (2012), “[Success DNA] SPC(4)Food Safety Management of President Hur," Dailian.

Jung, H. S (2007), "The growth of Finance and It's Economic Effects," The Korean Society of Management Cunsulting, 7(4), 131-147.

Kang, C. D (2012), “[Win-Win Franchise] Creation of Jobs for 124millions, Hankyung. Kim, G. T (2012), “Differentiation to Overcome NO.1," LG Business Insight, LGERI, 25-37. Kim, H, M., Lee, H. Y, and Lee, S. G. (2012), "A Study on Improvement of Franchise Trade Law from the Restaurant Franchisee Perspective," Journal of Foodservice $\mathrm{Ma}^{-}$ nagement, 15(1), 239-257.

Kim. H.. Woo. W, and Kang, H. G. (2013), "What explains the failure of Google in the Korean market? The Impact of Multicultural PR Strategy," ASIA MARKETING JOURNAL, 14(4), 35-56.

Kim, J. G (2012), "Creating Benefits, Upgrading Quality of Life, Foster Social Corporations," Dong-A Business Review, 117(2), 82-87.

Kim, S. G (2010), “The Induction of Competition Strategy," Seoul: Namuhangueru.

Kim, Y. H., T. H. Kim, and G. H. Oh (2011). "Breakiing Franchise Practice," SBS 8 News.

Kochak, J (2000), "Market Report - BAKERY CHAINS Donuts are back, bagels are lan- 
guishing and bakery cafes are expanding," Restaurant Business, 99(16), 81-91.

Lee, E. Y., and S. B. Lee (2011), "An Exploratory Study about Selection Attribute of Franchised Coffee House through AHP," Korean Journal of Hotel Administration, 20(4), 183-200.

Lee, H. J (2012). "How Should Domestic Agriculture cope with Environmental Change of Distribution," Hankook.

Lee, I. J (2012), "Paris Baguette, Opening Sixth Stores on Lotte Mart in Danang," Newsis.

Lee, J. H., and C. W. Kim (2011), "Model Building of Travel Intermediaries Global Value Chain," Jounal of Torism Research, 25(4), 329-344.

Lee, J. H., D. R. Choi., S. K. Lee. and J. G. Lee (2004), "Effect of Emulsifiers on Properties of the Bread Made by the Dough Frozen after First Fermentation," Journal of the Korean Society for Applied Biological Chemistry, 47(1). 107-112.

Lee, S. A (2012), "Multigrain Bread · Yeast Bread $\cdot$ Hub Bread $\cdots$ Now is Age of Meal Bread," Joongang.

Lee, S. B (2012), "Paris Baguette, Two Consecutive Years of NO.1 for Quality of Service Index ," MBN News,

Lim, Y. G., G. H. Ahn, And S. Y. Kim (2011). Channel Management. Paju: Hakhyunsa. Minichilli, A., Corbetta. G., and MacMillan. I (2010). "Top Management Teams in Family-
Controlled Companies: 'Familiness, 'Faultlines', and Their Impact on Financial Performance," Journal of Management Studies, 47(2), 438-448.

Moon, S. H(2006), "Baking Industry, Lowering Discount Rate to 2\%," Kyunghyang News. Orr, D (1967), "The Determinants of Entry: A Study of the Canadian Manufacturing Industries," The Review of Economics and Statistics, 75(4), 58-66.

Paris Croissant (2012), "Strategies of Paris Baguette," Internal Report, 1-32.

Park, C. S (2010), Principles of Marketing. $8^{\text {th }}$ edition. Paju: Bobmoonsa 2010.

Park, J. H (2012), "Paris Baguette-Tous Les Jours, Clash after 8 Years Overseas Expansion to Southeast Asian Market," NEWS1.

Park, S. H., and H. S. Park (2012), "Five Same Stores in $400 \mathrm{~m}$, High Benefits of Head Companies, Low Benefits of Affiliated Stores," Dong A News.

Porter, M (1990), "'The competitive advantage of nations," Harvard Business Review, March-April, 73-93.

Porter, M (2008), "The Five Competitive Forces That Shape Strategy," Harvard Business Review, 86(1), 3-18.

Porter, M., and Kramer. M. R (2011), "Creating Shared Value," Harvard Business Review, 89(2), 62-77.

Prahalad, C. K., and Hamel. G (1990), "The core competence of the corporation," Harvard Business Review, May-June, 79-91. 
Proctor, T (2000), Strategic Marketing: An Introduction, London: Routledge.

Rumelt, R. P (1984), Toward a strategic theory of the firm, Competitive Strategic Management, New York, NY: Prentice-Hall, 556570 .

Ryu, S. H., S. O. Kim, and S. Y. Seok (2011), "Difference in Bakery Choice Attributes according to Consumers' Characteristics and Purchasing Behavior," Journal of the Korean Society of Dietary Culture, 26(6), 673-681.

Ryu, S. M., G. H. Kim, and W. H. Lee (2012), "The analysis of Paris Baguette's global strategies." Korea Distribution Association, 2012(6), 173-180.

Seo, Y. K., J. W. Kim, and S. Y. Cho (2011), "How to make Successful SNS Strategies for corporations," Information systems review, 13(3), 1-13.

Siderera, Y., Maquet. A., and Anklab. E (2005), "Need for research to support consumer confidence in the growing organic food market," Trends in Food Science \& Technology, 16(8), 332-343.
Song, M., Roger. J., Calantone. C., and Benedetto. A (2002), "Competitive forces and strategic choice decisions: An experimental investigation in the United States and Japan," Strategic Management Journal, 23(10), 969-978

SPC (2006). "SPC 60". Seoul: SPC.

Srivastava, R. K., Shervani. T. A., and Fahey. L (1998), "Market-Based Assets and Shareholder Value: A Framework for Analysis," Journal of Marketing, 62(1), 2-18.

The Korea Chamber of Commerce \& Industry (2011), "Business Outlook of Franchise Industry for The First Half Year in 2011," The Korea Chamber of Commerce \& Industry .

The Korea Chamber of Commerce \&Industry (2012), "Business Outlook of Franchise Industry for The First Half Year in 2012," The Korea Chamber of Commerce \& Industry.

Van Ravens, J (1994), “The Franchise Model: A New Way of Funding and a Tool for Change?." Tertlary Education and Management, 1(1), 81-90. 


\section{〈Appendix〉}

Appendix 1. Cross Impact Analysis Matrix on the External Environment

\begin{tabular}{|c|c|c|c|c|c|c|c|}
\hline \multicolumn{8}{|c|}{ Level of Dependence } \\
\hline & $\begin{array}{l}\text { Restriction of } \\
\text { Franchisee } \\
\text { Expnnsion }\end{array}$ & $\begin{array}{l}\text { Increase in } \\
\text { Production Cost }\end{array}$ & $\begin{array}{l}\text { Dwindiling } \\
\text { Household Spending }\end{array}$ & $\begin{array}{l}\text { More attention } \\
\text { Creating Shared } \\
\text { Value }\end{array}$ & $\begin{array}{l}\text { Increase in } \\
\text { Well-being Trend }\end{array}$ & Spread of SNS & $\begin{array}{l}\text { Totaf influence Levei } \\
\text { (Absolute Value) }\end{array}$ \\
\hline $\begin{array}{l}\text { Restriction of } \\
\text { Franchisee } \\
\text { Expansion }\end{array}$ & & 2 & 0 & 0 & 0 & 0 & 2 \\
\hline $\begin{array}{l}\text { Increase in } \\
\text { Production Cost }\end{array}$ & 0 & & 2 & 0 & 0 & 0 & 2 \\
\hline $\begin{array}{l}\text { Dwindling } \\
\text { Household Spending }\end{array}$ & 1 & 0 & & 1 & -1 & 0 & 3 \\
\hline $\begin{array}{l}\text { More attention } \\
\text { Creating Shared } \\
\text { Value }\end{array}$ & 2 & 2 & 0 & & 0 & 1 & 5 \\
\hline $\begin{array}{l}\text { Increase in } \\
\text { Well-being Trend }\end{array}$ & 0 & 1 & -1 & 0 & & 0 & 2 \\
\hline Spread of SNS & 1 & 0 & 0 & 1 & 1 & & 3 \\
\hline $\begin{array}{l}\text { Total Dependence } \\
\text { Level } \\
\text { (Absolute Value) }\end{array}$ & 4 & 5 & 3 & 2 & 2 & 1 & \\
\hline
\end{tabular}

Appendix 2. Cross Impact Analysis Quadrant on the External Environment

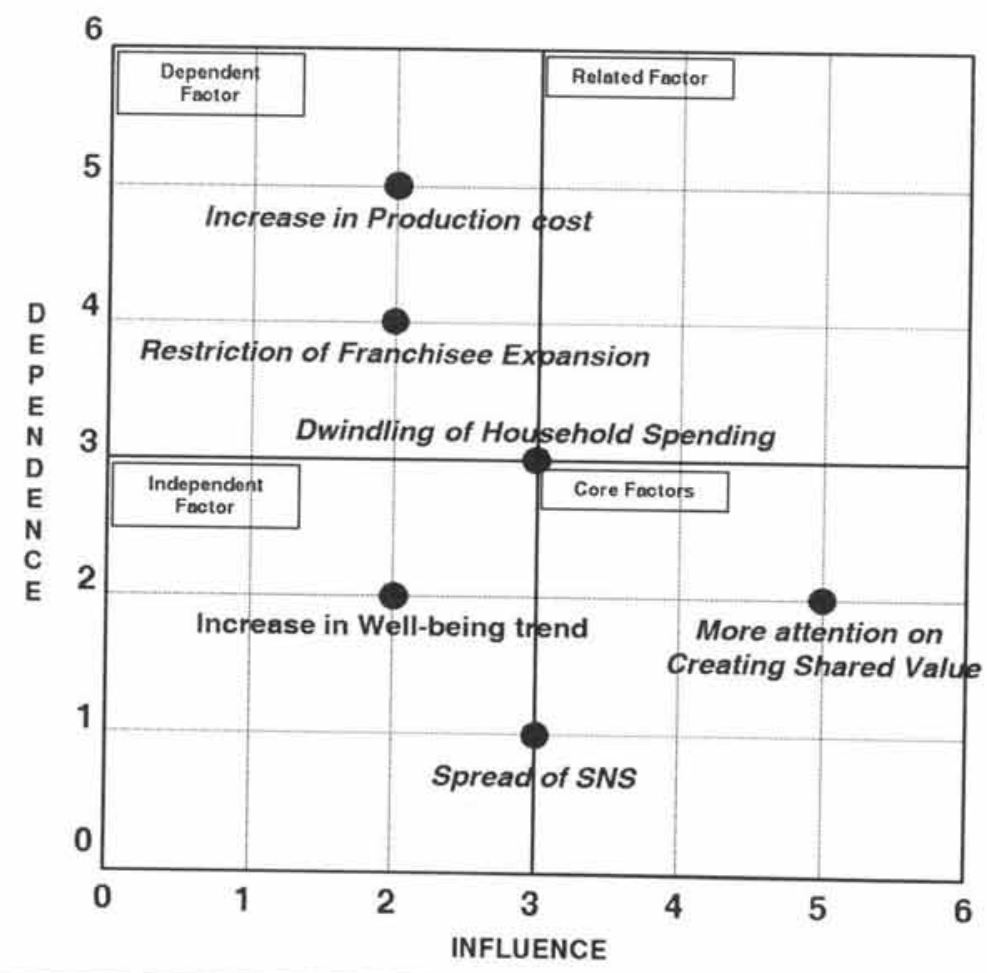




\section{Appendix 3. Five Forces Model}

Appendix 3 contains a detailed analysis of the five forces that make up the Five Forces Model as mentioned in the present study.

\section{1) Threat of New Entrants}

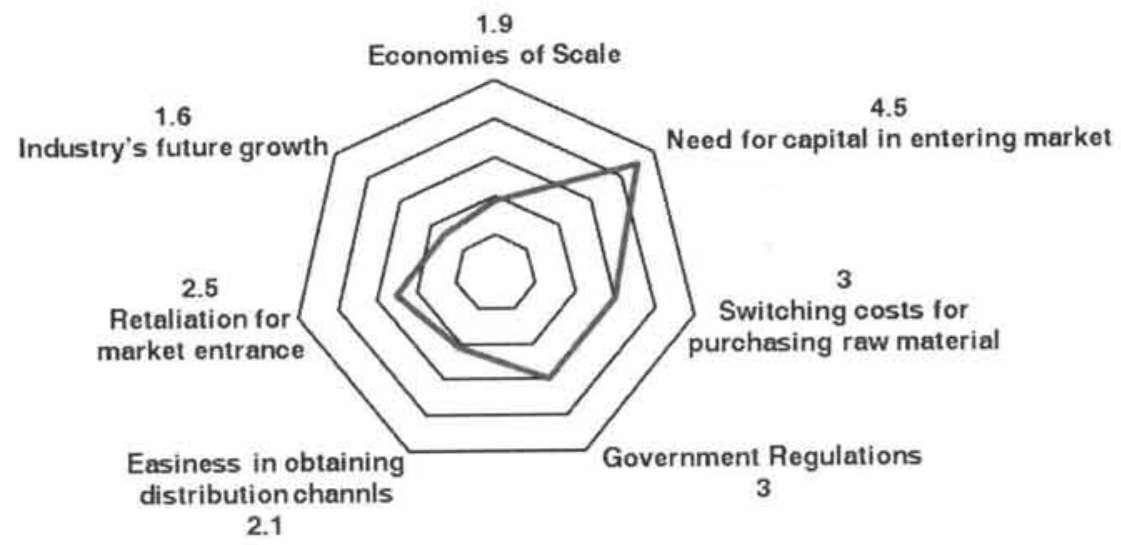

Barriers to new entrants act both as a device to maximize profits for existing companies and as factors negatively affecting the market entry of new companies (Orr, 1974). A closer inspection of the general factors reveals that the bakery franchise industry poses some barriers to new entrants, proving to be somewhat difficult for newcomers to join. The public opinion of the industry is, however, that with appropriate know-how, it is easy to open a small shop. Recently. the "Win-Win Growth Committee" accepted the Korean Bakery Association's request for designating the bakery industry as an "SME-Suitable Business". With it, the growth of large bakery companies was regulated to a certain extent, and the barrier to new entrants lowered.

2) Industry Competition Intensity

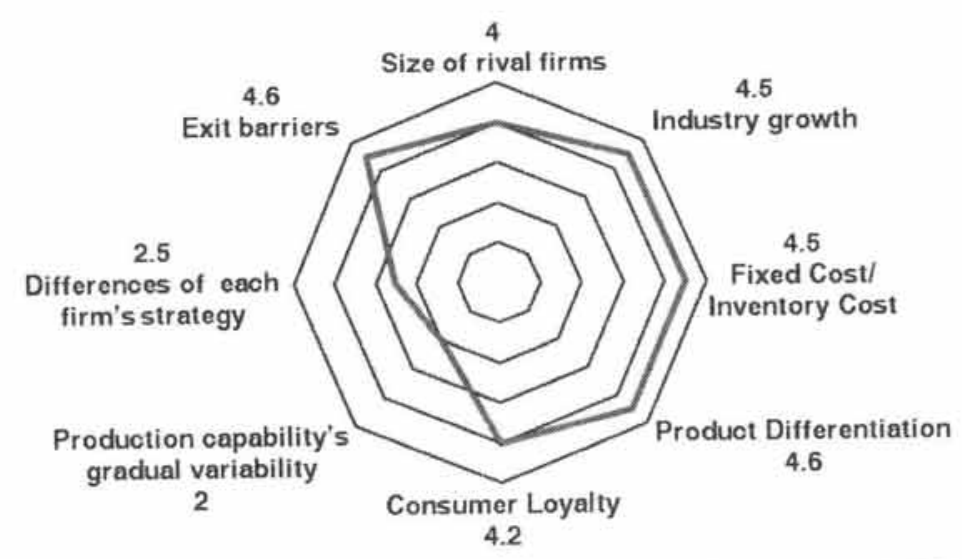


As the intra-industry competition intensifies, cutthroat competition prevails, thereby decreasing the profits of companies. With the increasing number of enterprises, the more similar their size, the greater the competition becomes (Porter, 2008). With regard to size, the leading company, Paris Baguette, had 2,675 stores in 2011, while Tous Les Jours had only 1,401 stores (Industry and Economics Division of Hankyung.com, 2012). Although Tous Les Jours' size is only $52 \%$ of Paris Baguettes. Tous Les Jours is an affiliated brand of CJ, a conglomerate holding various media and commercial-related business firms. Therefore, it has great growth potential, supported by its parent company, and with that potential in mind, it was given a relatively high score in terms of size among similar companies.

Meanwhile, when the growth potential of an industry is low, competition intensifies (Porter, 2008) since market saturation occurs quickly. Not only has the domestic bakery franchise market become saturated, but the outlook on the industry is also gloomy (Korea Chamber of Commerce and Industry, 2012).

3) Bargaining Power of Suppliers

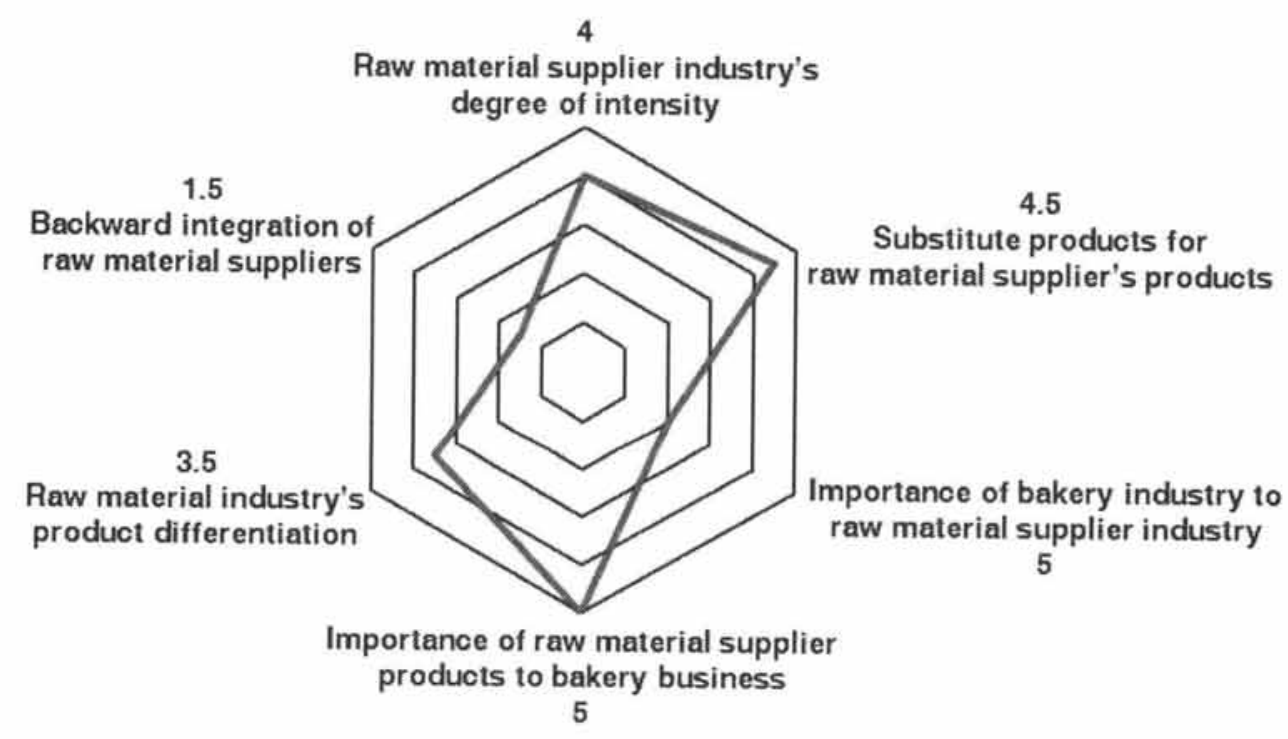

The bargaining power of suppliers can put pressure on companies when suppliers raise supply costs, thereby pushing up market prices, which become a burden for companies that buy from them (Porter, 2008). Flour, sugar, and milk, the main ingredients for bread, are as basic as materials can get, and almost no substitutes exist. Rye, the representative substitute for flour, is naturally sour, so consumer preferences are divided (Heiniö, et al., 2003). Therefore, the mere 
fact that no ingredient substitutes exist acts as a substantial threat: and in the same context, the importance of ingredient suppliers also acts as a major threat in the bread industry.

\section{4) Bargaining Power of Buyers}

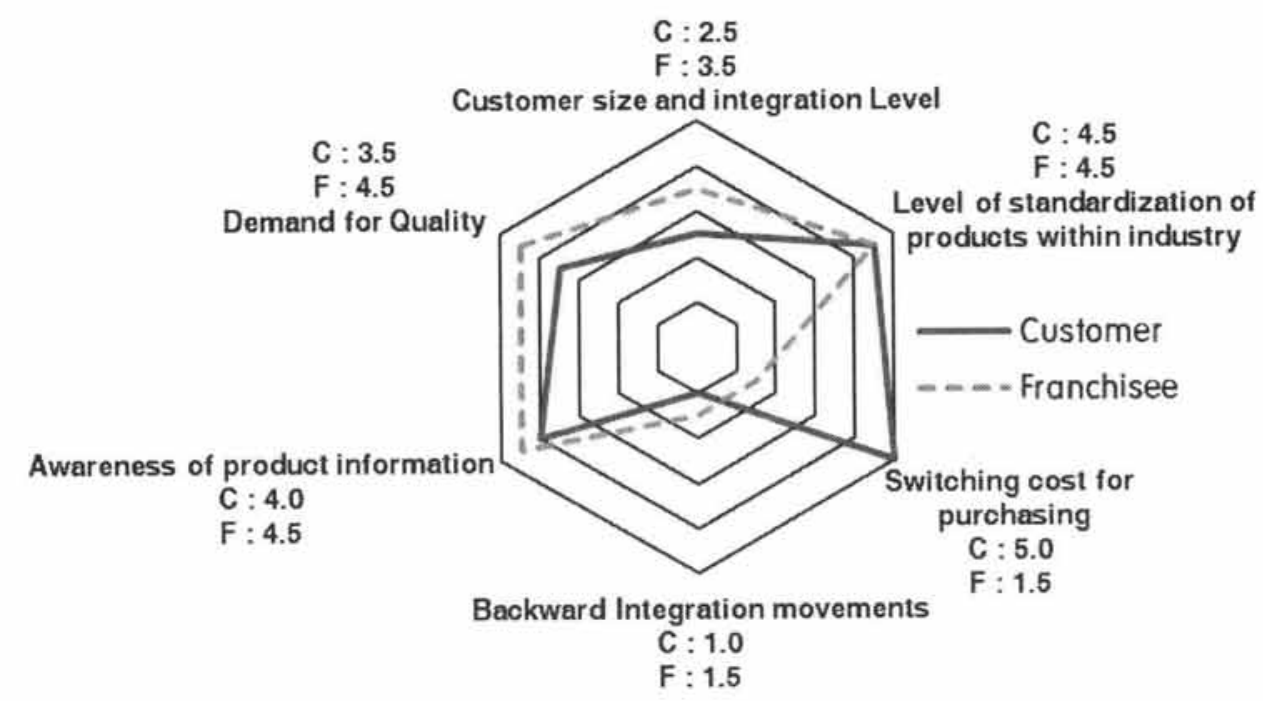

The analysis of buyers bargaining power was divided into the two groups of consumers and affiliated groups, due to the characteristics specific to the bakery franchise industry. From the franchise company's perspective, both affiliated stores that receive goods and pay the franchise company and consumers who consume the products through the affiliated stores are all consumers and buyers of the product, thus constituting two different consumer groups (Van Ravens, 1994).

First, from the consumer's perspective, consumers can easily gain information on the taste and smell of the product through acquaintances and Internet posts (Grunert \& Ramus, 2005). Also, as consumers' product standards are becoming increasingly refined (Siderera, 2005), so are the consumer demands on bakeries (Jung and Min, 2011). Such factors give consumers high bargaining power in relation to bakery franchise companies.

Meanwhile, if the buyer is viewed in terms of affiliated stores, a different result can be deduced. When an affiliated store changes the supplier, it means it changes the franchise company it has contractual agreements with (Fair Trade Commission, 2011). From the affiliated store's perspective, such changes incur high costs (Kim et al., 2011). However, since affiliated stores are the places where consumers purchase the franchising company's products, they demonstrate a higher demand for product quality than do consumers. 
5) Threat of Substitutes

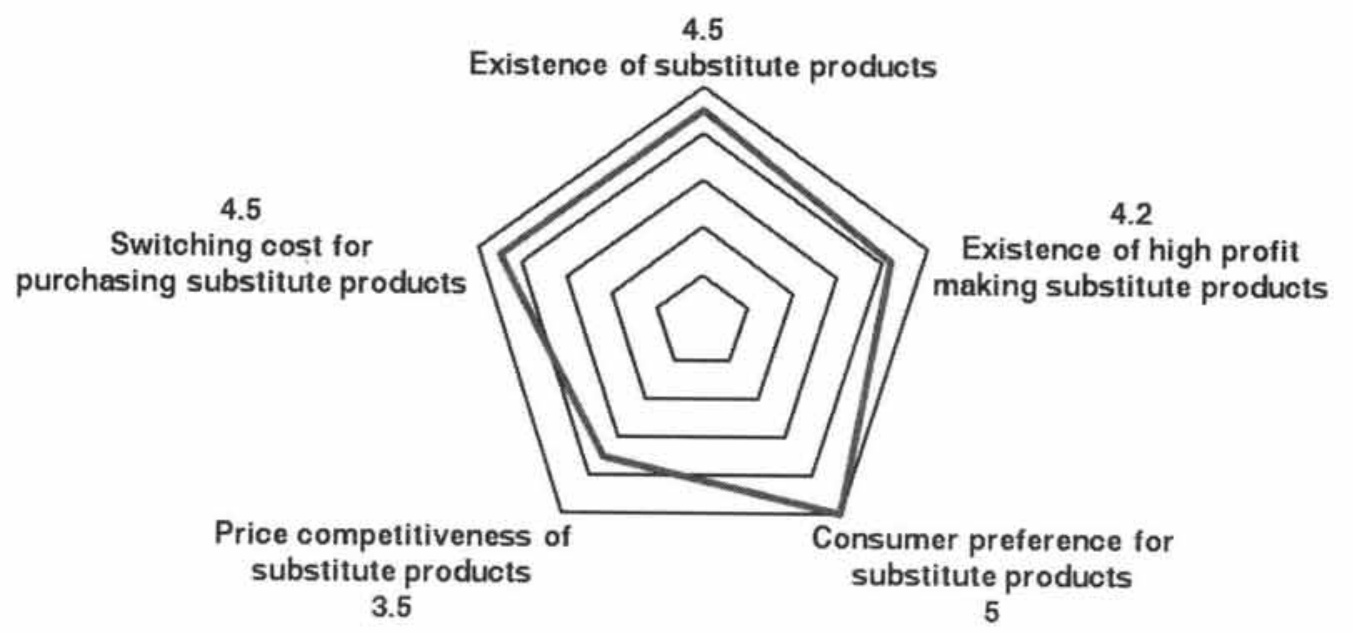

Out of the five forces that compose the Five Forces Model, the greatest threat to the domestic bakery franchise industry is that of substitutes.

Although bread is partially a staple product (Lee, 2012), for now it is consumed more as a snack (Ryu et al., 2011). Therefore, the entire food industry such as the café industry, confectionery industry, and the flour food industry can all be considered competitors providing substitutes. The existence of various substitutes itself acts as a great threat.

Meanwhile, among the various substitutes, the café industry is considered the one having the highest return compared to the bakery franchise industry (Kochak, 2000). The Korean café market has grown rapidly over the last few years (Lee and Lee, 2011). If this trend continues, it will become the main threat to the domestic bakery franchise. 